\title{
A.12 Royal Asiatic Society, London, Hodgson Ms. $55^{26}$
}

A Nepalese paper manuscript of 240 folios from 1791 CE (NS 911)

Saptaśatikā-prajñāpāramitā [163]

Prajñāpāramitā-dhāraṇī 37v [8,56]

Abhisamayālaṃkāra-nāma-prajñāpāramitopadeśaśāstra 51r

Pītavarṇa-prajñāpāramitā-dhāraṇi [55,162]

Prajñāpāramitā-dhāraṇī 51v [8,56]

Sarvajñatākāra-dhāraṇi 60r [53]

Saptabuddha-stava 63r

Șațpāramitā-hṛdaya-nāma-dhāraṇī 63v [59]

Yakșāșțaka-samyaksambuddhabhāṣita 64r [60]

Jambhalajalendrasya-nāma-dhāraṇi 64v [61]

Vasudhārā-nāma-dhāraṇī 79v [62]

Amoghapāśa-nāma-hṛdaya-mahāyānasūtra 87v [63]

Siṃhanādalokeśvarasya vyādhipraśamanī-dhāranī 88r [64]

"a short number of dhāranīs to 109r"

Mahāsāhasrapramardanī-nāma-vidyā-dhāraṇī 122r [78]

Mahāmāyūrī-vidyārājñ̄i-nāma-dhāraṇī 136v [79]

"a number of dhāraṇīs"

Bodhisattvacaryāprasthāna-daśabhūmīśvara-nāma-mahāyānasūtra-ratnarāja $148 \mathrm{v}[10]$

"a great number of dhāraṇis, stavas, stotras, etc."

Bhīmasena-stotra

26 After Cowell and Eggeling 1875: 41-42. Note that only selected texts are listed in the publication. I have not been able to consult the original manuscript or any reproductions. Titles given with minor standardizations. Corresponding text numbers in Cambridge Ms. Add. 1326 are given in square brackets (there is a chance of inconsistencies in the case of texts which appear by the same title more than once). 